\title{
Families in the Riveli di beni e anime of Gallodoro, Sicily during the Seventeenth and Eighteenth Centuries
}

Received: 26 June 2020 Accepted: 5 July 2020

Keywords: Gallodoro; Sicily; Riveli di beni e anime; Italian surnames; seventeenth century; eighteenth century

\author{
Eric Martone
}

\begin{abstract}
This article examines the riveli di beni e anime of the small town of Gallodoro, located in northeastern Sicily about halfway between the cities of Messina and Catania, to explore the history of the town's families during the seventeenth and eighteenth centuries by tracing the prevalence of surnames recorded in these documents. The growing proliferation of certain surnames suggests a longer presence of these families in Gallodoro, while the increasing diversification of surnames as a whole suggests a dynamic population comprised of new residents. Despite the diversification of surnames in the riveli for Gallodoro, during the seventeenth and eighteenth centuries, most of the town's population held only a relatively few different surnames.
\end{abstract}

Sicilian riveli di beni e anime (Registers of Goods and Souls), often referred to as census records, might perhaps be best understood as a combination of a modern census record, tax document, and local directory to record both possessions (beni) and inhabitants (anime). Taken periodically in Sicily from the sixteenth century to the early nineteenth century and often written in a mixture of non-standardized modern Italian, local Sicilian, Greek, and Latin, each rivelo typically listed the capo di casa (head of household), his (or her, in the event that the woman was unmarried or widowed) household members, property, and assets. The general structure of the records includes a preamble at the top of the first page wherein the capo di casa is named, often followed by his father's or parents' names (or the name of the deceased husband in the case of a widow). In the text of each rivelo, under the heading of anime, the capo di casa is again named, as well as the other household members with their relationship to the head (including estimated ages for all males listed). Women were generally listed under their married names, but some older riveli list women's maiden names. After listing the capo di casa's property and assets (and liabilities), each rivelo could conclude with the tax assessor's name or signature, the declarant's signature (if he was literate), witnesses' signatures, or the local parish priest's name or signature. In many cases, riveli also record in their inventory each capo di casa's nearest neighbors and associates within the town.

Local civil administrators filed riveli with the Tribunale del Real Patrimonio, which oversaw financial issues. In 1682, however, oversight of riveli shifted to the Deputazione del Regno. ${ }^{1}$ While often perceived as a land comprised primarily of poor, landless peasants, the riveli reveal that many common individuals within Sicily owned a house and at least a modest parcel of land. ${ }^{2}$ Primarily compiled to assess the population for tax revenue, as taxes were placed on people and possessions (including real estate, buildings, and animals), riveli also helped the government monitor the number of livestock and producing farmland available to supply food for the kingdom and the number of males eligible for military service or work on civil projects. ${ }^{3}$ The riveli thus contain statements of each capo di casa, including not only data on the composition of the family, but also the household's beni stabili ("stable assets," such as houses and land), beni mobili ("mobile goods," such as livestock) and gravezze (debts, rents, etc.). The animals were often divided into categories, such as caprai (goats); giumenta (mares); cavalla (horses); bovi (cattle); vacche (cows); pecore (sheep); asini (donkeys); and muli (mules). Riveli often list in their assessments of individuals' wealth various possessions, such as vineyards, orchards, groves, water wells, farm tools, sheds, silos, and household furnishings. Land, sized in hectares, was taxed by how it could be used, and was therefore divided into such categories as irrigatablili (capable of being irrigated), frumentale (for use growing grain), boschigne (for use as orchards), rampanti (on a hillside), and non pagano (not usable for generating income). Meanwhile, houses were often taxed based on the number of rooms on each floor. ${ }^{4}$

Riveli, generally bound in thick volumes with string threaded through two holes (one at the top corner and one at the bottom corner), are kept at the State Archive of Palermo and filed by the name of the town in alphabetical order according to one of the three valleys of Sicily: Val $\mathrm{Di}$

๑ 2021 The Author(s). This is an open access article distributed under the terms of the Creative Commons Attribution License (http://creativecommons.org/ licenses/by/4.0/) 
Mazara (western Sicily), Val Demone (northeastern Sicily), and Val Di Noto (southeast Sicily). ${ }^{5}$ Genealogists often regard riveli as supplemental records for parish church registers and other records. As riveli are typically a generation apart, an individual recorded as the capo di casa in one series of riveli can very well appear as the child of a capo di casa in the previous series. ${ }^{6}$ However, they provide many valuable and underappreciated insights into various aspects of the local histories of several Sicilian communities.

This article examines the riveli of the small town of Gallodoro (or Jaddudoru in modern Sicilian), located in northeastern Sicily about halfway between the cities of Messina and Catania, to explore the history of the town's families by tracing the prevalence of surnames recorded in these documents. The growing proliferation of certain surnames suggests a longer presence of these families in Gallodoro, while the increasing diversification of surnames as a whole suggests a dynamic population comprised of new residents. Part of the greater Taormina area (it was a hamlet, or frazione, of Taormina until 1634), Gallodoro had access to neighboring and more metropolitan areas despite its location in the Sicilian mountains. Gallodoro's frazione of Letojanni, known by the early 1700s as the "marina of Gallodoro," functioned as an extension between the main locality and the Ionian Sea. Gallodoro's population followed similar trends in other locations in Sicily and Southern Italy, in that it steadily continued to rise. However, the population in the frazione of Letojanni rose much higher during the course of the nineteenth century. As a result, the seat of the local government was transferred from Gallodoro to Letojanni in 1879; the comune (town) was subsequently known as Letojanni-Gallodoro until the two split into two separate comuni in 1952. ${ }^{7}$ During the course of much of its history, Gallodoro's middle and upper classes were within the cultural and social influence of the city of Messina. Even Gallodoro's most celebrated piece of art, // Gonfalone di Galladoro, is generally attributed to the school of Renaissance artist Antonello da Messina. ${ }^{8}$

The earliest riveli for Gallodoro date from its time as a hamlet of Taormina under the rule of the Spanish crown. ${ }^{9}$ While the 1583-1584 riveli are fragmentary, these documents reveal some of the surnames then common in Gallodoro, such as Cacopardo, Melita, Carpita, Lo Monaco, and d'Allura (sometimes spelled as "d'Alluri"). ${ }^{10}$ Further riveli were collected in 1593, 1607, 1616, 1623, 1652, 1680-1681, and 1747-1748. While the 1583-1584 and 1593 riveli are also fragmentary (and lacking indices), the well-preserved sets collected in 1607, 1616, 1623, 1652, 1680-1681, and 1747-48 are complete and have detailed indices listing each capo di casa included in the riveli. Throughout the riveli, surnames' spellings are widely inconsistent, even within the index for a given year. Further, sometimes the way in which an individual's surname is spelled in his or her rivelo does not match the way it is spelled in the index. Occasionally, none of these spellings are the same as the contemporary spelling or spelling variations. A final set of riveli was collected circa 1811 to 1816 , shortly before the broad introduction of civil records in 1820. The 18111816 riveli do not list the members of the household or include ages for any individuals; they are therefore focused exclusively on each capo di casa's economic condition.

Examining the $1607,1616,1623,1652,1680-1681$, and 1747-48 riveli demonstrate the demographic changes occurring within Gallodoro during the seventeenth and eighteenth centuries. These particular sets of records are relatively complete and spaced apart far enough to make such observations over time meaningful, as many of the town's early riveli are concentrated in the years 1583 to 1623 . Such an examination indicates that while the total number of households recorded in Gallodoro's riveli substantially increase from the seventeenth to the eighteenth century, the heads of these households possessed increasingly diverse surnames. Certainly not all individuals moving to Gallodoro during the sixteenth and seventeenth centuries would have had unique surnames, particularly as many of the surnames common in the town were also common within the larger Messina region. Nevertheless, this evidence is highly suggestive of a dynamic population within Gallodoro due in large part to the influx of new residents from neighboring towns and villages, rather than the growth of Gallodoro's existing population or families. Such evidence counters the notion that pre-industrial, agrarian-based societies contained families that remained largely fixed in the vicinity in which they were born.

\section{Gallodoro in the Seventeenth and Eighteenth Centuries}

Gallodoro, like much of Sicily, has ancient Greek origins. ${ }^{11}$ According to popular tradition, in ancient times an area known as Bocena existed near the location of the modern town. ${ }^{12}$ Archaeological evidence has also suggested the possible nearby location of the city of Kallipolis, founded by the same inhabitants of nearby Naxos (Giardini-Naxos), the first Greek colony in Sicily. The name of Kallipolis derived from the Greek words kalli, meaning "beautiful," and polis, meaning "city-state." The modern town of Gallodoro dates from the medieval period, during which time its borders and character began to take shape. Its first settlements formed around the rural Chiesa di San Teodoro. Over the centuries, Gallodoro expanded from this core, located in the heart of the Vallis Aurea, the name the ancient Romans gave to the valley, possibly referencing the existence of gold deposits. As late as 1781, an account from French scientist Dieudonné Dolomieu (also called Déodat De Gratet De Dolomieu, 1750-1801) commented on the numerous metal ore deposits, including gold, that existed in the Peloritani mountains area in which the city was located. ${ }^{13}$

The history of the mountain-based settlement of Gallodoro is also tied to that of its "marina," Letojanni. The origins of Letojanni are uncertain. It is possible that the coastal settlement of Letojanni resides near the location of the ancient Greek city of Lethaios. The ancient Romans 
Latinized this name as Letum lanum, which combined the toponym of "Leto" with the name of "Jano" to commemorate the god (Janus) to which they were devoted. The Roman Consul Valerio ordered the construction of a road that passed the town, the name of which likely evolved to Leto Jano, Leto Janne, and eventually Letojanni. A series of disastrous events and lack of a fortified defense system ultimately caused the original town's demise. ${ }^{14}$ It is probable that the ancient residents of Leto Janni, due to attacks on Sicily's shores, moved inland.

During the fourteenth century, Gallodoro's current mother church, the Chiesa di Santa Maria Assunta, was built (it was enlarged during the nineteenth century), while the smaller Chiesa di San Sebastiano was built during the fifteenth century. ${ }^{15}$ Many Renaissance-era religious artworks came to adorn the mother church, such as the altar-piece painted by Salvatore Mittica of Messina in 1607 and the processional banner of the holy crucifix (II Gonfalone di Galladoro) belonging to the school of Antonello da Messina. ${ }^{16}$

After a tumultuous medieval period shuffling under the control of various European and Mediterranean powers, Sicily largely fell under the authority of Spanish rulers from the fourteenth until the nineteenth centuries. Opposition to the French officials in control of Sicily in 1282 as a result of general mistreatment and high taxation had prompted a brutal local uprising known as the War of the Sicilian Vespers. ${ }^{17}$ During the course of this uprising, members of the Sicilian elite elicited support from Pero (Peter) III of Aragón (1239-1285). Pero soon seized control of Sicily from its French rulers, who retreated to the Kingdom of Naples. The French pope, Martin IV, encouraged a largely unsuccessful crusade against Pero III and the Kingdom of Aragón in 1283. Nevertheless, conflict continued until 1302 and the peace of Caltabellotta. As terms of this peace agreement, Pero III's son, Federico (Frederick) III (1272-1337), was recognized as the King of Trinacria (Sicily). During the fourteenth century, the Black Death also first reached Europe, devastating Messina. Meanwhile, Sicily largely remained an independent kingdom under the rule of relatives of the kings of Aragón until 1409, when it subsequently became integrated with the Crown of Aragón. ${ }^{18}$

Sicily, and Gallodoro in particular, became influenced primarily by Spanish culture during the modern era. ${ }^{19}$ In 1492 , Ferdinando (Ferdinand) II of Aragón (1452-1516) and his wife Isabella (Isabel) of Castile (1451-1504) united several Iberian kingdoms into the kingdom of Spain. They subsequently launched the Spanish Inquisition to root out non-Catholics. As part of this initiative, Jews were expelled from Sicily. ${ }^{20}$ Ferdinando and Isabella's heir, Juana (Joanna), known to history as "Juana la Loca" ("Joanna the Mad"), married Felipe (Philip) I (1478-1506) of the powerful Austrian House of Habsburg. Their Habsburg descendants exerted control over Sicily from the early 1500 s to 1713 by virtue of being kings of Spain and the lands of the Spanish crown. ${ }^{21}$

While the continuous control of Sicily by Spanish rulers might ostensibly have created a greater sense of political stability, revolts against Spanish rule during the 1600 s, particularly those of Palermo and Messina, were crushed with brutal force. ${ }^{22}$ Eastern Sicily, where Gallodoro was located, was also rocked by massive earthquakes in 1542 and 1693 as well as outbreaks of plague. Further, raids from North African pirates continued to ravage Sicily until the nineteenth century. ${ }^{23}$ Such raids, which had been ongoing for centuries, helped discouraged renewed settlement along the Sicilian coast and encouraged continued settlement further inland in the mountains, as the case with Gallodoro.

Meanwhile, the evolution of the town's name of Gallodoro reflected the growing Latinization and Italianization of the original Greek name and local Sicilian culture. Within the Latin-based renderings of the town's name, the "K" was often replaced with a "C." In 1562, for example, Francesco Maurolico mentioned the locality in his contemporary account as "Callidorum," or "Callidorium." Similarly, in 1574, Tommaso Fazello referred to the town as "Callidorus." 24 Both renderings reflect the Latinization of the name of the town, which lies in the heart of the Valle Aurea. Latin records could sometimes state "Kallis Aurei," "Callis Aurei," or later, "Galli Aurei," suggesting how the name evolved from the Latin words vallis ("valley") and aureus/aurea/aureum ("gold" or "golden"). Such Latin words are the basis for modern Italian words valle ("valley"), oro ("gold"), and d'oro ("of gold" or "golden"). Thus, combining derivatives of the Latin words for "valley" and "gold/golden" evolved into renderings of the town's name such as "Callidorum" or "Callidorus." ${ }^{25}$ Records from the end of the sixteenth century onward increasingly state "Gallidorus" or "Gallidoro," with the letter "G" steadily taking the place of the "C." In a form of Italianization, "Kallidoro" thus became "Callidoro" or "Gallidoro," which evolved to Gallodoro (in the local Sicilian dialect, however, the "K" is preserved, as the name is rendered as "Kaddidoru" or "Kadditori"). ${ }^{26}$

From 1422 to 1634 , Gallodoro remained a hamlet under the larger town of Taormina's administrative authority. Until the first half of the seventeenth century, the comparatively sparsely populated coastal territory that included Letojanni was also divided between the towns of Taormina and Forza d'Agrò. In the 1630s, during the reign of Felipe (Philip) IV, the part of this shared territory that included Letojanni, along with the hamlet of Gallodoro, was detached from Taormina and sold by the Royal Court to Donna Francesca Porzio, wife of Don Francesco Reitano of Messina, who in 1637 was awarded the title of "Marchese di Gallidoro." Thus, the noble Reitano family of Messina received autonomy over the municipality, which was now part of the marquisate of Gallodoro. ${ }^{27}$ 
Although Spain had emerged as a great world power during the Age of Exploration, it fell into decline following the 1659 Treaty of the Pyrenees, which ended the Franco-Spanish War of 1648-1659 launched as part of the Thirty Years' War. France's status as a world power, however, increasingly expanded as a result of this victory. Although in decline, Spain still held sway over a vast global empire that included territory in the Americas, Asia, and other parts of Europe, including the Spanish Netherlands, Sicily, and parts of the Italian peninsula. A powerful navy was crucial for the maintaining of this empire, but rivals like France, the Netherlands, and England challenged this naval authority. The Habsburg dynasty ruling Spain adopted conservative socio-economic policies, serving as a firm advocate of the Roman Catholic Church, the nobility, and a system of privileges. During the War of Devolution (1667-1668)-a conflict between France and Spain for control of the Spanish Netherlands (contemporary Belgium and Luxembourg)_Spanish forces had difficulty halting French advances.

By the 1670s, France and Spain were again at war as part of the Franco-Dutch War. In 1672, a revolt broke out in the city of Messina. At the forefront of this revolt were artisans, who seized control of the city from the notables then in control of the local government. Like many Sicilian municipalities at the time, Messina had been controlled by an oligarchy of notable families. Often interpreted as a popular revolt against an oppressive ruling class, the Messina revolt did not acquire anti-Spanish overtones until the local notables regained control of the city in 1674 and subsequently expelled the Spanish governor and solicited French aid. The city of Messina was among the most significant municipalities in Sicily. With over 120,000 residents during the early seventeenth century, the city was important strategically. As a fortress city, whoever controlled it could exert authority over the Straits of Messina as well as hold off potential invasions. The French government sent several expeditions to assist Messina. In turn, the Dutch, as allies of Spain, sent a fleet to blockade Messina. French efforts to break this blockade were thwarted at the Battle of Etna in 1676. Meanwhile, other municipalities under Messina's sway were forced to choose sides. Some ultimately decided to maintain allegiance with Spain while others made the decision to side with Messina and the French. Messina held out until a peace was negotiated in 1678 . The French subsequently withdrew their assistance and Spain regained control. ${ }^{28}$

After Don Antonio Reitano and members of his family allied themselves with a pro-French faction of notables during the Anti-Spanish Revolt of Messina (1674-1678), the family was exiled and its assets-including the Marquisate of Gallidoro-were confiscated in $1677 .{ }^{29}$ Other rebellious families faced similar repercussions. The Royal Court sold Gallodoro to Don Stefano Oneto and the title of "Marchese di Gallidoro" to Agesilao Bonanno. However, the king did not approve such sales, according to his ordinance issued in 1677 and executed in 1678. By 1679, Gallodoro was transferred to Don Giuseppe Vigo. The noble Vigo family of Acireale exercised control over the territory for several decades. ${ }^{30}$ During that time, local artisans carved the town's small, but marvelous Chiesa di Santa Maria Maddelena out of rock, near the location of the former Chiesa di San Teodoro.

During the eighteenth century, the War of the Spanish Succession (1701-1714), initiated due to the death of childless Habsburg king Carlos (Charles) II (1661-1700), ravaged Europe and had a profound impact on Sicily. ${ }^{31}$ The Spanish crown ruled over a vast global empire at the time, and three competing claimants for the throne-coming from the royal houses of France (Bourbon), Austria (Habsburg), and Bavaria (Wittelsbach)—could not reach an amicable solution. Before his death, Carlos II had named his grandnephew, Felipe, Duc d'Anjou (16831746), the second eldest grandson of Louis XIV of France, as his heir. However, the other Europeans feared that control of both France and Spain by the House of Bourbon could upset the European balance of power. The peace of Utrecht (1713), which ended this conflict, recognized Felipe, Duc d'Anjou, as Felipe (Philip) V of Spain and the founder of the Spanish branch of the Bourbon royal dynasty. ${ }^{32}$

The peace agreements also transferred Sicily to the House of Savoy. However, after seven years, the king of Savoy exchanged Sicily for the Italian island of Sardinia with Charles VI of the Austrian Habsburg Dynasty. ${ }^{33}$ The Habsburg family's control of Sicily, however, was short-lived. While the Austrians were preoccupied with the War of the Polish Succession (1733-1735), a Spanish army conquered Naples and Sicily, both of which were then under Habsburg rule. Carlo (Charles), Duca di Parma e Piacenza (1716-1788), a younger son of Felipe V of Spain, was placed on the thrones of Naples and Sicily. Sicily was initially able to retain its status as an independent kingdom under personal union while the Bourbon king ruled over both from Naples; this status lasted until the early nineteenth century. ${ }^{34}$

Despite such political changes for Sicily, Gallodoro remained a comparatively stable community. Previous scholars, using church records and other documents such as riveli, have estimated that the population of Gallodoro (including Letojanni) remained relatively steady at an average of 1,184 residents between 1623 and 1792, with a low of 1,135 individuals circa 1636 and a high of 1,246 individuals circa 1651 (see Figure 1). ${ }^{35}$ During the seventeenth century, the modern settlement of Letojanni continued to develop as a small fishing village under the administrative control of Gallodoro. By the eighteenth century, as political stability regained a foothold in Sicily, Letojanni emerged as a small, but thriving village_known as the "marina of Gallodoro"—comprised of a few houses, inhabited primarily by laborers, artisans, and families of fishermen. ${ }^{36}$ 
Figure 1. Total Population of Gallodoro. ${ }^{37}$

\begin{tabular}{ll}
\hline Year & $\begin{array}{l}\text { Estimated Population of } \\
\text { Gallodoro (including Letojanni) }\end{array}$ \\
\hline 1623 & 1,140 \\
1636 & 1,135 \\
1651 & 1,246 \\
1681 & 1,186 \\
1733 & 1,196 \\
1748 & 1,180 \\
1792 & 1,202 \\
\hline
\end{tabular}

During the mid-1700s, the population of Letojanni had grown enough to establish its own parish. ${ }^{38}$ The first baptism recorded independently in Letojanni was that of Alfio Ardizzone (1764-1840), son of Maestro Matteo di Alfio Ardizzone of Acireale and Giuseppa Pagano on Feb 1, 1764; his godparents were Gaetano Galeano and Cristina Galeano. ${ }^{39}$ During the second half of the eighteenth century, using parish baptism records, scholars estimate Letojanni's average population at about 349 residents, almost 1/3 of the total population of Gallodoro. ${ }^{40}$

With the abolition of feudalism in 1812 and the establishment of the Comuni in 1816, Gallodoro became an autonomous municipality. Social, political, and economic shifts during the nineteenth century prompted the population of Letojanni to expand rapidly. ${ }^{41}$ Even many of Gallodoro's most prominent families began building elaborate homes in the seaside community. As a result of Letojanni's higher growth rates in comparison to Gallodoro during the nineteenth century, the decision was made in 1879 to transfer the seat of local government from Gallodoro to Letojanni, with the former becoming a frazione (an administrative subdivision) of the latter. This new municipal entity, known as "Letojanni-Gallodoro," remained in place until 1952, when Gallodoro and Letojanni formally dissolved into two separate towns.

\section{Surnames and Households in the Riveli of Gallodoro}

During the collection of the 1607 riveli, Gallodoro was still attached to the municipality of Taormina. The documents, therefore, identify Gallodoro (spelled as "Gallidoro") as a "casale di Taormina." ${ }^{42}$ A casale was generally "an isolated village within the territory of a city" that often had "no administrative autonomy" and thus "under the civil and penal jurisdiction of the city from which" it depended. Within Sicily, casali were often small villages and agricultural settlements. ${ }^{43}$ The name Gallodoro is also rendered variously as "Gallidoro" or "Callidoro" in the different riveli. The 1607 riveli present information on 278 households in Gallodoro, and represent all, or nearly all, households in the hamlet. Surnames are spelled inconsistently, and letters such as "o" and " $\mathrm{u}$, " and "i" and "e," are often used interchangeably. Articles, such as "lo" and "di" are used inconsistently for certain surnames. ${ }^{44}$

An analysis of the 1607 riveli reveals that the capi of these households had 62 different surnames. However, a majority of residents had only a handful of different surnames. Of the 278 recorded households in Gallodoro, 143 (51 percent) were headed by individuals with one of only seven different surnames: Cacopardo, Melita, di Todaro, Lo Turco, Carpita, Stracuzzi, and d'Allura. Meanwhile, in 1607, 20 of the 278 capi of these households (7 percent) had surnames belonging to only one household, but these surnames accounted for 20 of the 62 ( 32 percent) total number of different surnames in the town.

Figure 2. Families in Gallodoro in 1607.

\begin{tabular}{ll}
\hline Surname & Number of Household Heads with Surname \\
\hline Cacopardo & 36 \\
(di) Melita & 29 \\
di Todaro/di Thodaro & 23 \\
(Lo) Turco & 19 \\
Carpita & 16 \\
Stracuzza/Stracuzzi & 11 \\
di Alluri/di Allura (d'Allura) & 9 \\
Lo Monaco & 8 \\
Sgroy (Sgroi) & 8 \\
Vuliti (Guliti) & 6 \\
Mattarella & 5 \\
Vulotta (Gulotta) & 5 \\
\hline
\end{tabular}


Figure 2. (Continued).

\begin{tabular}{|c|c|}
\hline Surname & Number of Household Heads with Surname \\
\hline Curcuruto & 4 \\
\hline Legato/Ligato & 4 \\
\hline Lombardo/Lumbardo & 4 \\
\hline Lo Scavo (Lo Sciavo) & 4 \\
\hline Strazzeri & 4 \\
\hline Bucceri & 3 \\
\hline Cammareri & 3 \\
\hline Cingari & 3 \\
\hline Giardina & 3 \\
\hline Lo $\operatorname{Re}$ & 3 \\
\hline Parisi & 3 \\
\hline Tornaturi (Tornatore) & 3 \\
\hline Trischitta & 3 \\
\hline Russo & 3 \\
\hline Starantino (Starrantino) & 3 \\
\hline Viruari & 3 \\
\hline di Xacca (Sciacca) & 3 \\
\hline Zoy (Zoi) & 3 \\
\hline di Blasi & 2 \\
\hline Ciccio & 2 \\
\hline D’evola & 2 \\
\hline Marino & 2 \\
\hline Nuciforo/Nucifora & 2 \\
\hline Paguni & 2 \\
\hline Lo Piscopo & 2 \\
\hline Quagliata/Cuagliata & 2 \\
\hline Quartararo & 2 \\
\hline Rusulello (Russolillo) & 2 \\
\hline Vincinguerra & 2 \\
\hline Zimbali & 2 \\
\hline di Agostino (d'Agostino) & 1 \\
\hline di Artali & 1 \\
\hline Blundo & 1 \\
\hline Brundo (Biondo) & 1 \\
\hline Bunaci (Bonaci) & 1 \\
\hline Calo & 1 \\
\hline Carccotto (Carciotto) & 1 \\
\hline Crisafulli & 1 \\
\hline Foti & 1 \\
\hline Gatto & 1 \\
\hline Grimaldo & 1 \\
\hline di Leo & 1 \\
\hline Malvasia & 1 \\
\hline Musculino (Muscolino) & 1 \\
\hline di Noto & 1 \\
\hline Rudilosso & 1 \\
\hline Scarlata & 1 \\
\hline Silvestri & 1 \\
\hline Vaccaro & 1 \\
\hline La Vecchia & 1 \\
\hline Total Number of Households & 278 \\
\hline
\end{tabular}


Less than a decade later, another series of riveli was collected in $1616 .{ }^{45}$ During the collection of the 1616 riveli, Gallodoro was still attached to the municipality of Taormina. The records more consistently identity Gallodoro as "Gallidoro" (and more specifically as "Gallidoro di Taormina") in the different riveli. The 1616 riveli record 281 households in Gallodoro, representing an increase of three households over those recorded in 1607. Again, such a number likely represents all, or nearly all, households in the hamlet. Surnames are spelled inconsistently, and letters such as "o" and " $u$, " "i" and "e," and " $c$ " and "z," are often used interchangeably. Articles, such as "di," are used inconsistently for certain surnames.

An analysis of the 1616 records indicates that the capi of these households, despite being larger in number, had fewer different surnames than those in 1607 (59 instead of 62). However, similar to the prior riveli, a majority of residents had only a handful of different surnames. Of the 281 households in Gallodoro, 152 (54 percent) were headed by individuals with one of only seven different surnames: Cacopardo, Melita, Lo Turco, di Todaro, Stracuzzi, Carpita, and d'Allura; these surnames were the same seven most common ones recoded in the 1607 riveli. Meanwhile, in 1616, 21 of the 281 capi of these households (7 percent) had surnames belonging to only one household, but these surnames accounted for 21 of the 59 (36 percent) total number of various surnames in the town. Moreover, ten of the households (17 percent) possessed surnames not recorded previously in the 1607 riveli. In Figure 3, the surnames not appearing in earlier riveli analyzed in this article are identified by grayshaded boxes.

Figure 3. Families in Gallodoro in 1616.

\begin{tabular}{ll}
\hline Surname & Number of Household Heads with Surname \\
\hline Cacopardo & 46 \\
(di) Melita & 27 \\
Lo Turco & 22 \\
Carpita & 16 \\
di Thodaro/di Todaro & 16 \\
Stracuzzi & 16 \\
d'Allura/Gallura & 9 \\
Sgroi & 9 \\
Lo Monaco & 8 \\
Guliti & 7 \\
Bocceri/Bucceri & 5 \\
Gulotta & 5 \\
Tornatori (Tornatore) & 5 \\
Cingali/Cingari & 4 \\
Corcuruto/Curcuruto & 4 \\
Legato/Ligato & 4 \\
Lombardo & 4 \\
Parisi & 4 \\
Lo Re & 4 \\
Lo Scavo/Lo Schiavo & 4 \\
Zimbalo/Zimbali/Cimbali & 4 \\
Gardina/Giardino/Giardina & 2 \\
Mattarella & 2 \\
Russo & 2 \\
di Blasi & 2 \\
Birbiri/Birbari & 2 \\
Camareri/Cammareri & 2 \\
Marino & 2 \\
Nuciforo & 2 \\
Rosolello (Russolillo) & 2 \\
Starrantino & 2 \\
Strazzeri & 2 \\
Quaglata/Quagliata & 2 \\
Quartararo & 2 \\
Vaccaro & 2 \\
Lo Vayro/Vairo & 2 \\
Vinciguerra & 2 \\
Zoi & \\
\hline
\end{tabular}


Figure 3. (Continued).

\begin{tabular}{ll}
\hline Surname & Number of Household Heads with Surname \\
\hline d'Agostino & 1 \\
Bueulo/Bueolo (from Casalvecchio Siculo) & 1 \\
Biundo (Biondo) & 1 \\
Bonaci & 1 \\
Cacciola & 1 \\
Cardone & 1 \\
Ciccio & 1 \\
Gatto & 1 \\
Grimaldo & 1 \\
Gugliotti (Gugliotta) & 1 \\
di Leo & 1 \\
Mascolina (Muscolino) & 1 \\
Pagano & 1 \\
Paguni & 1 \\
Parlaturi (Parlatore) & 1 \\
Lo Piscopo & 1 \\
Rigoloso (Rudilosso) & 1 \\
Saia & 1 \\
Scarlata & 1 \\
Trischitta & 1 \\
Xharciotta (Carciotto) & 1 \\
Total Number of Households & $\mathbf{2 8 1}$ \\
\hline
\end{tabular}

The 1623 riveli were the last to be collected prior to the detachment of Gallodoro from the town of Taormina. ${ }^{46}$ Consequently, the records identify Gallodoro as a "casale di Taormina." The 1616 riveli usually refer to Gallodoro as either "Gallidoro/Gallodoro" or "Callidoro/Callidori," marking the first instances in the riveli in which the contemporary spelling of the town's name ("Gallodoro") appears. The 1623 riveli for Gallodoro record only 177 capi of households, a decline of 104 households over those recorded in 1616 . Surnames are spelled inconsistently, and letters such as "o" and "u," "i" and "e," and "v" and "g," are often used interchangeably. Articles, such as "lo," "la," and "di," are used inconsistently for certain surnames.

Despite the reduction in number, the capi of these households in the 1623 riveli possess 47 different surnames, nearly the same as in 1616. Similarly, 100 of the 177 households in Gallodoro (56 percent) were headed by individuals with one of only six different surnames: Cacopardo, Melita, Carpita, Lo Turco, Stracuzzi, and di Todaro. These six surnames were also among the most frequently recorded surnames in the 1607 and 1616 riveli. While only 22 of the 177 heads of households (12 percent) had unique surnames, these surnames accounted for 22 of the 47 (47 percent) total number of different surnames in the town. Of these various surnames, five of them (3 percent) were not recorded previously in the 1607 or 1616 riveli, including Severino and Longo.

Figure 4. Families in Gallodoro in 1623.

\begin{tabular}{ll}
\hline Surname & Number of Household Heads with Surname \\
\hline Cacopardo & 34 \\
(di) Melita & 19 \\
Carpita & 13 \\
(Lo) Turco & 13 \\
Stracuzzi/Stracuzzo & 12 \\
(di) Todaro & 9 \\
Vuleti/Guleti/Vuliti/Guliti & 7 \\
d'Allura/d'Alluri & 6 \\
Bucceri & 4 \\
Lo Monaco & 4 \\
Lo Re & 3 \\
Sgroi & 3 \\
Stornaturi/Tornaturi/Turnaturi (Tornatore) & 3 \\
Vulotta/Gulotta & 3 \\
Auccello/Aucello & 2 \\
di Blasi & 2 \\
Cingili/Cingali (Cingari) & 2 \\
\hline
\end{tabular}


Figure 4. (Continued).

\begin{tabular}{ll}
\hline Surname & Number of Household Heads with Surname \\
\hline Ciccio & 2 \\
Curcuruto & 2 \\
Parisi & 2 \\
Rosso (Russo) & 2 \\
Saija (Saia) & 2 \\
La Scavo/Lo Scavo (Lo Sciavo) & 2 \\
Strazzeri & 2 \\
Viruari & 2 \\
Cintirrino (Cintorrino) & 1 \\
Bonaci & 1 \\
Camareri (Cammareri) & 1 \\
L'Episcopo (Lo Piscopo) & 1 \\
Foti & 1 \\
Quartararo & 1 \\
Gatto & 1 \\
Giardena (Giardina) & 1 \\
Intalisano/Intelisano & 1 \\
Ligato & 1 \\
Lombardo & 1 \\
Longo & 1 \\
Musculino (Muscolino) & 1 \\
Pagano & 1 \\
Paguni & 1 \\
Quagliata & 1 \\
Nuciforo & 1 \\
Rudilosso & 1 \\
Scarlata & 1 \\
Severino & 1 \\
Starrantino & 1 \\
Vaccaro & 1 \\
Total Number of Households & 1 \\
\hline
\end{tabular}

Recorded nearly a quarter of a century later, the 1652 riveli no longer typically use a " $\mathrm{C}$ " when rendering the town's name, referring to it as either "Gallidoro" or "Gallodoro." 47 Surnames are still spelled inconsistently, and letters such as " $\mathrm{o}$ " and " $u$," " $\mathrm{i}$ " and "e," " $\mathrm{z}$ " and " $\mathrm{c}$, " " $\mathrm{c}$ " and "ch," " $\mathrm{x}$ " and "ch," and "l" and " $\mathrm{d}$ " (reflecting local dialects), are often used interchangeably. Articles, such as "lo" and "di," are used inconsistently for certain surnames. The 1652 riveli for Gallodoro record only 96 capi of households, the lowest of any riveli collected in the seventeenth and eighteenth centuries. This represents a drastic decline in the number of households recorded in the 1652 riveli for Gallodoro in comparison to those in 1623. This contrasts with scholars' estimates of the town's population size from 1623 to 1651 based on other records, suggesting an increase of roughly 100 residents. ${ }^{48}$ Consequently, the 1652 riveli cannot be viewed as representing the town as a whole.

The capi of the households in the 1652 riveli nevertheless possess 36 different surnames. As in previous riveli, the majority of households (52) were headed by individuals with only a handful of different surnames. These surnames comprise 54 percent of all recorded households. These most common surnames were again Cacopardo, Melita, Lo Turco, Stracuzzi, d'Allura, di Todaro, and Carpita. Six of these surnames were also the most frequently recorded surnames in the 1607, 1616, and 1623 riveli. Despite the fewer households recorded in the 1652 riveli, 20 of the 96 heads of households (21 percent) had unique surnames, a much higher percentage of unique surnames than in previous riveli. Moreover, these surnames accounted for 20 of the 36 ( 56 percent) total number of different surnames in the town. Of these various surnames, nine of them ( 25 percent) were not recorded previously in the 1607, 1616, or 1623 riveli. Among these surnames were Galletta, Musca (Mosca), and Pauluci (Polluce).

Figure 5. Families in Gallodoro in 1652.

\begin{tabular}{ll}
\hline Surname & Number of Household Heads with Surname \\
\hline Cacopardo & 12 \\
(di) Melita & 9 \\
Lo Turco/Turcho & 9 \\
Stracuzzi & 8 \\
d'Allura/d'Addura & 5 \\
(di) Todaro/Theodaro & 5 \\
Carpite/Carpita & 4 \\
Gulotta & 4 \\
Sarrentino/Starantino/Starrantino & 4 \\
Musculino (Muscolino) & 3 \\
\hline
\end{tabular}


Figure 5. (Continued).

\begin{tabular}{ll}
\hline Surname & Number of Household Heads with Surname \\
\hline Sgroi & 3 \\
Lo Monaco & 2 \\
Parisi & 2 \\
Lo Re & 2 \\
Rosolello & 2 \\
Tornaturi (Tornatore) & 2 \\
d'Uvello (d'Avello) & 1 \\
Agliotta & 1 \\
di Blasi & 1 \\
Zuccato & 1 \\
Cammareri & 1 \\
Ciccio & 1 \\
Galletta & 1 \\
Guliti & 1 \\
Mauro & 1 \\
Musca (Mosca) & 1 \\
di Natale & 1 \\
Pauluci (Polluce) & 1 \\
Pauni & 1 \\
Pipi & 1 \\
Quartararo & 1 \\
Russo & 1 \\
Severino & 1 \\
Strazzeri & 1 \\
(di) Xiacca (Chiocca) & 1 \\
Zingaro (Cingari) & 1 \\
Total Number of Households & 96 \\
\hline
\end{tabular}

The second half of the seventeenth century was a calamitous era. Around 1665, a wave of the plague spread throughout Sicily. Four years later, Mount Etna erupted, causing massive devastation to the surrounding area. In 1693, earthquakes brought renewed destruction to the nearby Catania region. ${ }^{49}$ Consequently, scholars estimate that the population of Gallodoro experienced a modest decline from 1651 to $1681 .{ }^{50}$ Nevertheless, in 1680-1681, 256 households were recorded in Gallodoro for the riveli, indicating a growth of 160 households since 1652 and representing a more accurate portrait the town's total population. ${ }^{51}$ Surnames are spelled inconsistently, and letters such as "o" and " $u$," and "i" and "e," are still often used interchangeably. Articles, such as "Io," "la," and "di," are used inconsistently for certain surnames.

An analysis of the 1680-1681 riveli indicates that these 252 household heads had 69 different surnames (which is greater than the previous highest number of 62 diverse surnames recorded in the 1607 riveli). Similar to the situation in 1607, 1616, 1623, and 1652, a majority of residents had only a handful of different surnames. Of the 252 households in Gallodoro, 132 (52 percent) were headed by individuals with one of only seven different surnames: Cacopardo, Melita, Lo Turco, Stracuzzi, Lo Monaco, di Todaro, and Carpita. Six of these seven most popular surnames overlap with those in 1607, 1616,1623 and 1652. However, this set of riveli marks the first time in which the surname Lo Monaco emerged in the top seven most frequently recorded surnames in Gallodoro. Meanwhile, 37 of 252 household heads ( 15 percent) had surnames belonging to only one household, but these surnames accounted for 37 of the 69 ( 54 percent) total surnames in the town. Further, 24 of the 69 different surnames ( 35 percent) appearing in the index of the 1680-1681 riveli were absent from those of 1607, 1616, 1623, and 1652. The increase in the number of both the total and unique surnames can be attributed to an influx of new residents to Gallodoro over the course of the mid-seventeenth century. While some possessed the same surnames of residents in the town, many had different surnames—including Mangano, Celi, Parlaturi (Parlatore), Raneri, and Roggeri (Ruggeri)—-that added to the diversity of surnames.

Figure 6. Families in Gallodoro in 1681.

\begin{tabular}{ll}
\hline Surname & Number of Household Heads with Surname \\
\hline Cacopardo/Cocopardo & 37 \\
Melita & 26 \\
(Lo) Turco & 18 \\
Stracuzzi/Stracuzza & 16 \\
Lo Monaco/Lo Monico & 14 \\
(di) Todaro/Thodaro & 13 \\
Carpita & 8 \\
Gulotta & 7 \\
d'Allura/Vallura & 7 \\
Guliti & 6 \\
\hline
\end{tabular}


Figure 6. (Continued).

\begin{tabular}{|c|c|}
\hline Surname & Number of Household Heads with Surname \\
\hline (di) Sgroi & 5 \\
\hline Bucceri & 5 \\
\hline Starrantino/Sterrantino & 5 \\
\hline (La) Musca/Musco (Mosca) & 4 \\
\hline Tornaturi/Turnaturi (Tornatore) & 4 \\
\hline Quartarara/Quartararo & 4 \\
\hline di Blasi & 3 \\
\hline Longo & 3 \\
\hline Strazzeri & 3 \\
\hline Vaccaro & 3 \\
\hline (di) Celi & 2 \\
\hline Cingari & 2 \\
\hline Curcuruto & 2 \\
\hline Manganaro/Munganaro & 2 \\
\hline Mattarella & 2 \\
\hline La Mota/La Motta & 2 \\
\hline Nogariti/Nogareti & 2 \\
\hline Pagano & 2 \\
\hline Paguni & 2 \\
\hline Parlaturi (Parlatore) & 2 \\
\hline Pauni & 2 \\
\hline Lo Re & 2 \\
\hline d'Agliotta & 1 \\
\hline Cambareri & 1 \\
\hline Carioffalo (Carofalo) & 1 \\
\hline Carravuci & 1 \\
\hline Ciccio & 1 \\
\hline di Eroi & 1 \\
\hline Falli & 1 \\
\hline Foti & 1 \\
\hline Gatto & 1 \\
\hline Grillo & 1 \\
\hline Intelisano & 1 \\
\hline di Leo & 1 \\
\hline Lombardo & 1 \\
\hline Mangano & 1 \\
\hline Marino & 1 \\
\hline Muscolino & 1 \\
\hline Paluci (Polluce) & 1 \\
\hline Parisi & 1 \\
\hline Pittinato (Pettinato) & 1 \\
\hline Lo Piscopo & 1 \\
\hline Raneri & 1 \\
\hline Rao & 1 \\
\hline Roggeri (Ruggeri) & 1 \\
\hline Rosoladdo (Russolillo) & 1 \\
\hline Russo & 1 \\
\hline Santoro & 1 \\
\hline Savoca & 1 \\
\hline Scarlata & 1 \\
\hline di Sciata & 1 \\
\hline Sergi & 1 \\
\hline di Simone & 1 \\
\hline Suiglia (Suglia) & 1 \\
\hline Lo Terzo & 1 \\
\hline Viola & 1 \\
\hline Virculi & 1 \\
\hline Viruici & 1 \\
\hline Zuccato & 1 \\
\hline Total Number of Households & 252 \\
\hline
\end{tabular}


The 1747-1748 riveli are the only set of such records collected in Gallodoro during the eighteenth century. ${ }^{52}$ The $1747-1748$ riveli recorded 355 households in Gallodoro with a total population of 1,151 residents. This set of riveli also includes a detailed index, listing each member of every household in the town. These records also distinguish residents of Letojanni, as it was under Gallodoro's administrative authority at that time. These residents are typically identified in these documents as residing at the "marina of Gallodoro." The total number of households represents an additional 103 households, or a 41 percent increase, from those in 1681 . While slightly inflated by the gradually accumulating number of residents settling along the "marina of Gallodoro" (Letojanni), whose marginal population numbers are included in this total, this figure nevertheless represents a substantial rise in Gallodoro's population. While surnames could still be spelled inconsistently, there are fewer spelling variations within the records as a whole; moreover, letters such as "o" and " $\mathrm{u}$," and " $\mathrm{i}$ " and "e," are still often used interchangeably. However, the records consistently record the name of the town in its contemporary spelling of "Gallodoro."

The 1747-1748 riveli indicate that these 355 household heads had 82 different surnames (a 19 percent growth over the number of different surnames in 1681). Similar to the situation in seventeenth-century riveli, a majority of residents had only a handful of different surnames. Of the 355 households in Gallodoro, 191 (54 percent) were headed by individuals with one of only seven different surnames: Cacopardo, Lo Turco, Melita, Stracuzzi, Lo Monaco, Gulotta, and Carpita. Five of these seven most popular surnames overlap with those recorded in the 1607, 1616, 1623,1652 , and 1681 riveli, while six of them overlap with the most popular surnames from 1681 . However, this set of riveli marks the first time in which the surname Gulotta entered this list of most frequently recorded surnames, as well as the first set of riveli in which the surname di Todaro was absent. Both the surnames di Todaro and d'Allura, which had appeared among the most frequently recorded surnames in earlier riveli, while both still present in Gallodoro, were not among even the most frequently recorded 12 surnames in the 1747-1748 riveli.

Meanwhile, in 1747-1748, 42 of 355 household heads (12 percent) had surnames belonging to only one household, but these surnames accounted for 42 of the 82 ( 51 percent) total surnames in the town. Further, 43 of the 82 different surnames ( 52 percent) appearing in the index of the 17471748 riveli were absent from those of $1607,1616,1623,1652$, and 1681. Among these surnames were Siliato (Siligato), Miano, Bonsignore, Currente (Currenti), Fucili, Prega Dio (Pregadio), and Scimuni (Scimone). The increase in the number of both the total and unique surnames can be attributed to a continued influx of new residents to Gallodoro that began in earnest during the mid-seventeenth century.

Figure 7. Families in Gallodoro (including Letojanni) in 1747-1748.

\begin{tabular}{ll}
\hline Surname & Number of Household Heads with Surname \\
\hline Cacopardo & 55 \\
Lo Turco & 34 \\
Melita & 32 \\
Stracuzzi & 22 \\
Lo Monaco & 22 \\
Gulotta & 14 \\
Carpita & 12 \\
Musca (Mosca) & 9 \\
Parisi & 8 \\
Guliti & 7 \\
Ruggeri/Rugeri & 7 \\
Sgroj (Sgroi) & 7 \\
(lo) Russo & 6 \\
di Todaro & 6 \\
Turnaturi (Tornatore) & 5 \\
Celi & 4 \\
Intellisano & 4 \\
Longo & 4 \\
Parlatore & 4 \\
Lo Re & 4 \\
Ricca & 4 \\
Bucceri & 3 \\
Polluce & 3 \\
Siliato (Siligato) & 3 \\
Strazzeri & 3 \\
Vinciguerra & 3 \\
d'Allura & 2 \\
Bartulotta (Bartolotta) & 2 \\
di Blasi & 2 \\
Campagna & 2 \\
Cingari & 2 \\
Conti & 2 \\
\hline
\end{tabular}


Figure 7. (Continued).

\begin{tabular}{|c|c|}
\hline Surname & Number of Household Heads with Surname \\
\hline Manganaro & 2 \\
\hline Miano & 2 \\
\hline Muscolino & 2 \\
\hline Pauni & 2 \\
\hline Quartoraro (Quartararo) & 2 \\
\hline Ristifo (Restifo) & 2 \\
\hline Scordo & 2 \\
\hline Vaccaro & 2 \\
\hline Ardizzone & 1 \\
\hline Ariale & 1 \\
\hline Bonsignore & 1 \\
\hline Boso & 1 \\
\hline Bruno & 1 \\
\hline Cannata & 1 \\
\hline Camarda & 1 \\
\hline Caracciolo & 1 \\
\hline Carbonaro & 1 \\
\hline Cardone & 1 \\
\hline Curciotto (Carciotto) & 1 \\
\hline Currente (Currenti) & 1 \\
\hline Fama & 1 \\
\hline Fleres & 1 \\
\hline Foti & 1 \\
\hline Fucili & 1 \\
\hline Galeano & 1 \\
\hline Galioti & 1 \\
\hline Galletta & 1 \\
\hline Lanzafame & 1 \\
\hline di Luca & 1 \\
\hline Maddi & 1 \\
\hline Manueli & 1 \\
\hline Mattarella & 1 \\
\hline Micuzzo & 1 \\
\hline Occhino & 1 \\
\hline Pagano & 1 \\
\hline Prega Dio (Pregadio) & 1 \\
\hline Prispita & 1 \\
\hline di Puglia & 1 \\
\hline Pumallitto & 1 \\
\hline Quattrocchi & 1 \\
\hline Radazzo & 1 \\
\hline Rascaria & 1 \\
\hline Rumeo (Romeo) & 1 \\
\hline Saja (Saia) & 1 \\
\hline Sangnibene (Sagnibene) & 1 \\
\hline Scimuni (Scimone) & 1 \\
\hline Scripilliti & 1 \\
\hline Solano & 1 \\
\hline Spataro & 1 \\
\hline Valentino & 1 \\
\hline Total Number of Households & 355 \\
\hline
\end{tabular}

\section{Conclusion}

An analysis of the $1607,1616,1623,1652,1680-1681$, and 1747-48 riveli for Gallodoro indicates that the town's seventeenth- and eighteenthcentury population, despite a relatively stable total size, was likely dynamic rather than static. The heads of the households recorded in these records possessed increasingly diverse surnames. While it is possible some families moving to Gallodoro would have had the same surname as some residents already in the town, especially as several of these surnames are common in the region, such diversification nevertheless suggests the continued arrival of new town residents rather than the growth of the existing population and families. Such evidence presents a portrait of more mobile pre-industrial, agrarian-based societies. 
Nevertheless, as riveli indicate that Gallodoro's population maintained close relations with its neighboring towns, it is probable that the majority — but certainly not all_of new residents to Gallodoro came from such surrounding towns as Taormina, Castelmola, Giardini, Graniti, Limina, Roccafiorita, Casalvecchio Siculo, Mongiuffi Melia, Forza d'Agrò, and Savoca. Sometimes the origin of these new residents is recorded in the riveli, but often this is not the case. An example of this, however, occurs in the 1747-1748 rivelo for Antonio Siliato (Siligato), who is identified as originating from Mongiuffi Melia. ${ }^{53}$ Indeed, the populations of the towns of Gallodoro and Mongiuffi Melia in particular had regular interactions with each other, with some even owning property in both towns. ${ }^{54}$ Relationships such as these likely created some fluidity between the towns' populations as well as marriage agreements that resulted in relocations to Gallodoro (and vice versa). ${ }^{55}$

However, some families came from farther away, including the city of Messina. For example, among the new family surnames to appear in Gallodoro during the mid-seventeenth century was that of Mosca. ${ }^{56}$ The family's entry and settlement in the town was typical of the other new families arriving in Gallodoro at the time. The town's riveli, which typically record the surname as "Musca" (similar to the Latin form of the name), indicate that the first individual with this surname to be recorded in the riveli for Gallodoro was Antonino Mosca of Messina. His 1652 rivelo identifies his place of origin, as well as his parents' names as Petro (Pietro) Mosca and Antonia. Based on his given age, he was born around 1616. His assets were not extensive, and he was involved in agricultural work. ${ }^{57}$ His spent the remainder of his life in Gallodoro and was survived by his wife, Catherina Sgròi, who is identified as his widow during the next set of riveli recorded in $1680-1681 .^{58}$

Between the 1652 and 1680-1681 riveli, however, three more families with the surname of Mosca appear in Gallodoro. The first of which was the family of brothers Diego and Nicolao Mosca. This rivelo identifies their parents as Maestro Carlo Mosca and Domenica. Diego's given age suggests an estimated birth date of 1651 . Since his family does not appear among the 1651 riveli, he and his family may have moved to Gallodoro after his birth. ${ }^{59}$ Another Mosca family recorded in the 1680-1681 riveli was that of Maestro Giacomo Mosca. Although Giacomo had died young before the completion of the 1680-1681 riveli, his wife, Francesca (who had remarried by that time), and three sons are included among these records. These three sons, born during the 1670s, were Carlo, Domenico, and Giovanni Battista Mosca. ${ }^{60}$ Among Giacomo Mosca's grandchildren was Marco Mosca, recorded in the 1747-1748 riveli. Born around 1722, Marco married Domenica Lo Monaco in Gallodoro during the 1740 s. $^{61}$

Meanwhile, the other Mosca family recorded in the riveli for Gallodoro between the 1652 and 1680-1681 riveli was that of Francesco Mosca, whose male descendants in the town continued to multiply during the eighteenth and nineteenth centuries (Figure 8). He, too, died young before the riveli were collected, but his son, Simone (b.c. 1667), and daughters and are listed twice: Simone has his own rivelo including his sisters and they also all appear with their mother, Maria, in the rivelo of her second husband, Pietro Cacopardo. ${ }^{62}$ With his wife, Agata, Simone Mosca's direct descendants included two influential priests of Gallodoro recorded in the 1747-1748 riveli: his son, Don Pietro Mosca (b.c. 1706), and grandson, Don Simone (or Simeone) Mosca (b.c. 1716). ${ }^{63}$

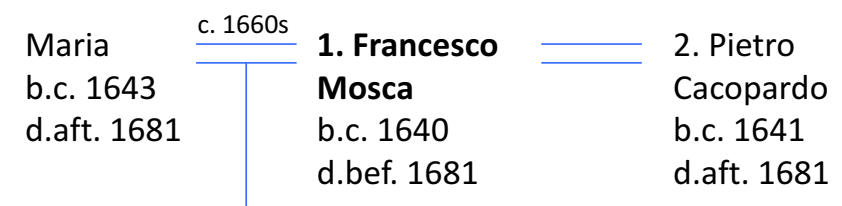

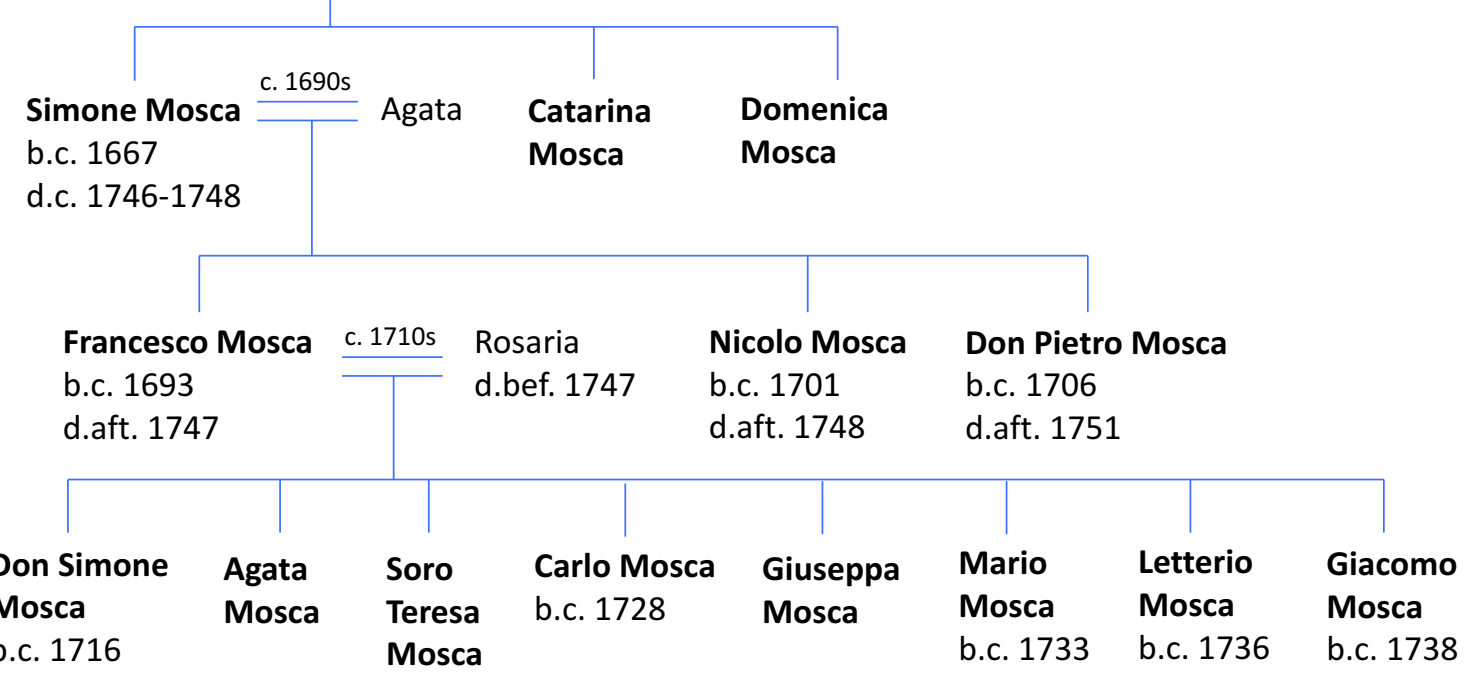

Figure 8. Family Tree of Francesco Mosca. 
Figure 9. Ten Most Common Surnames in the Riveli of Gallodoro, 16071748.

\begin{tabular}{lll}
\hline Surname & Number of Households & Percentage of All Recorded Households \\
\hline Cacopardo & 220 & $15 \%$ \\
Melita & 142 & $10 \%$ \\
Lo Turco & 115 & $8 \%$ \\
Stracuzzi & 85 & $6 \%$ \\
di Todaro & 72 & $5 \%$ \\
Carpita & 69 & $5 \%$ \\
Lo Monaco & 58 & $4 \%$ \\
Gulotta & 38 & $3 \%$ \\
d'Allura & 38 & $3 \%$ \\
Sgroi & 35 & $2 \%$ \\
Others & 572 & $40 \%$ \\
\hline
\end{tabular}

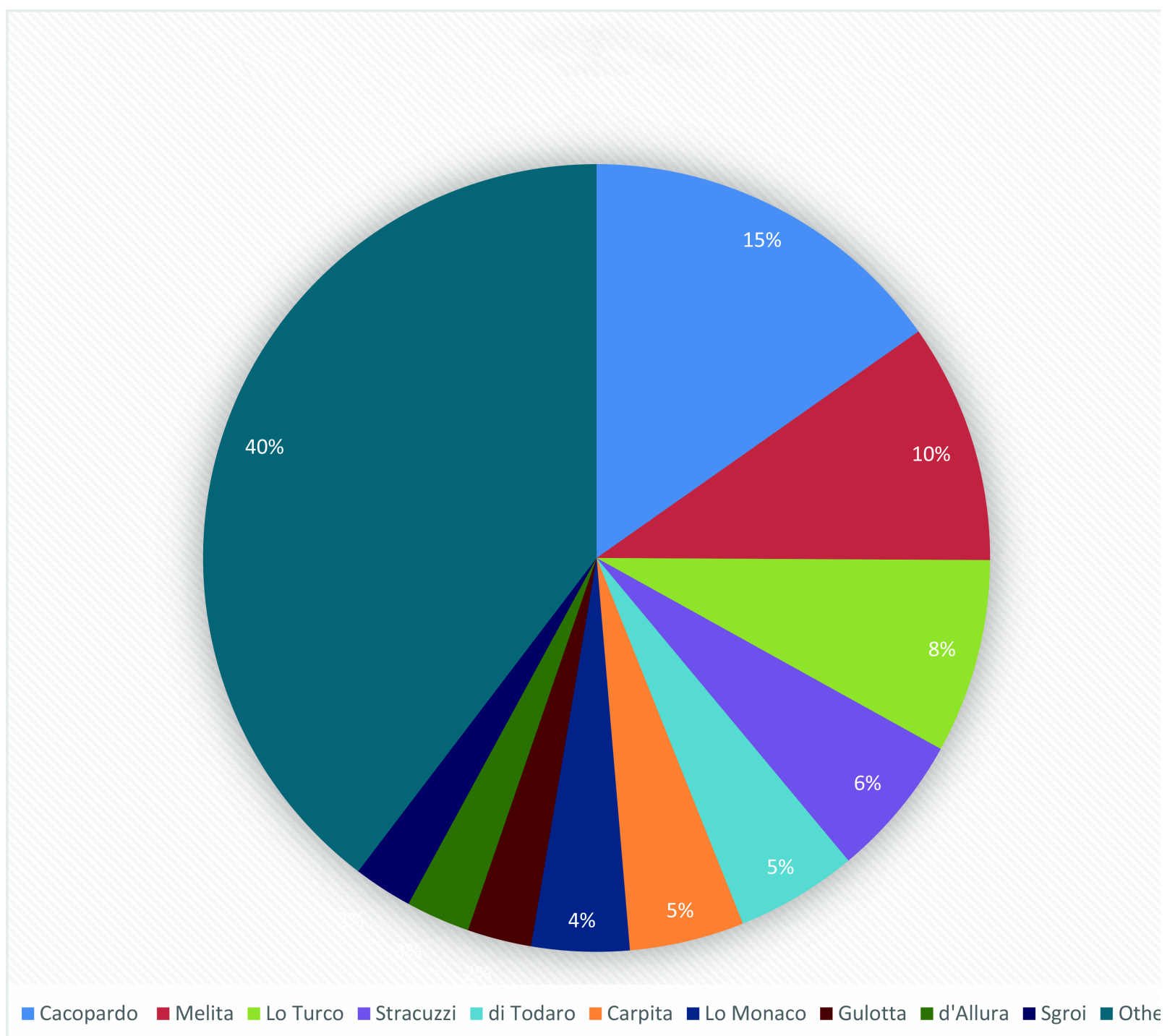

Figure 10. Surnames in the Riveli of Gallodoro, 1607-1748. 
Despite the diversification of surnames in the riveli for Gallodoro during the seventeenth and eighteenth centuries, most of the town's population held only a relatively few different surnames. The surnames of Cacopardo, Melita, Carpita, Lo Turco, and Stracuzzi appear most frequently among the most common surnames in each collection of riveli among the residents of Gallodoro during the seventeenth and eighteenth centuries; these surnames likely have histories in Gallodoro dating from at least the early 1500s. However, when aggregating the data during the period, the six most common historical surnames to appear are Cacopardo, Melita, Lo Turco, Stracuzzi, di Todaro, and Carpita. Families recorded with these surnames are therefore among those with the deepest historical roots in the town. Looking at the data (see Figures 9 and 10), while the 10 most common surnames accounted for 60 percent of all 1,444 recorded households, the two most common surnames-Cacopardo and Melita-accounted for 25 percent of all 1,444 households recorded in the riveli from 1607 to 1748 .

\section{References}

1. Peytavin, Mireille. (2006) 'Government/Administration: The Italian Kingdoms within the Spanish Monarchy'. Cochrane, Lydia G. trans. In: Spain in Italy: Politics, Society, and Religion 1500-1700, Dandelet, Thomas and Marino, John, eds. Leiden, Netherlands: Brill. p. 355-382.

2. Martino, John. (2006) 'The Rural World in Italy under Spanish Rule'. In: Spain in Italy: Politics, Society, and Religion 1500-1700, Dandelet, Thomas and Marino, John, eds. Leiden, Netherlands: Brill. p. 405-429.

3. Taxation was generally at the rate of 10 percent of the value.

4. See: Ligresti, Domenico. (2002) Dinamiche demografiche nella Sicilia moderna, 15051806. Milan, Italy: FrancoAngeli.

5. Archivo di Sato di Palermo, Palermo, Sicily, Italy. See: https://www.saassipa.benicul turali.it/patrimonio-archivistico/strumenti-di-ricerca/: accessed 3 April 2021.

6. See: Mendola, Louis. (2013) Sicilian Genealogy and Heraldry. New York: Trinacria Editions.

7. Scimone, Nino and Triolo, Mario. (2002) Letojanni: Storia, Immagini, Personaggi. Acireale, Italy: Massimino Editrice.

8. See: Mosca, Salvatore. (2012) I/ Gonfalone "Antonelliano" di Gallodoro. Messina, Italy: Armando Siciliano Editore.

9. Digital copies of the riveli for Gallodoro held in the Archivo di Sato di Palermo can be accessed through FamilySearch. See: Riveli di beni e anime, Gallodoro (Messina), 1584-1816. Salt Lake City, Utah: Filmati dalla Genealogical Society of Utah, 1994 2004. https://www.familysearch.org/search/catalog/747688?availability=Family\% 20History\%20Library: accessed 3 April 2021.

10. Riveli 1584, Films 2381814 and 2381815, Riveli di beni e anime, Gallodoro (Messina), 1584-1816. Salt Lake City, Utah: Filmati dalla Genealogical Society of Utah, 1994 2004. https://www.familysearch.org/search/catalog/747688?availability=Family\% 20History\%20Library/: accessed 3 April 2021.

11. Matthews, H.C. (2020) Greek Cities of Sicily: History, Archaeology, Architecture. H.C. Matthews; De Angelis, Franco. (2018) Archaic and Classical Greek Sicily: A Social and Economic History. New York: Oxford University Press; Jonasch, Melanie, ed. (2020) The Fight for Greek Sicily: Society, Politics, and Landscape. Oxford: Oxbow.

12. D’Agostino, P. (1987) Gallodoro: Un Paese di Antica Civiltá del Territorio di Taormina. Messina: Ed. Sfameni.

13. Scimone and Triolo, Letojanni, p. 63-64

14. Ibid. p. 57-59, 63-64.

15. It now serves as a small museum for holy art.

16. Much later, in 1906, sculptor Antonino Lo Turco of Monguiffi Melia carved bas relief engravings on the high altar depicting stories of the Virgin Mary.

17. See: Runciman, Steven. (1992) The Sicilian Vespers: A History of the Mediterranean World in the Later Thirteenth Century. New York: Canto/Cambridge University Press; Mendola, Louis. (2016) Sicily's Rebellion against King Charles: The Story of the Sicilian Vespers. New York: Trinacria Editions.

18. See: Bisson, Thomas N. (1991) The Medieval Crown of Aragon: A Short History, rev. ed. New York: Clarendon Press/Oxford University Press; Fancy, Hussein. (2016) The Mercenary Mediterranean: Sovereignty, Religion, and Violence in the Medieval Crown of Aragon. Chicago: University of Chicago Press; Ryder, Alex. (1990) Alfonso the Magnanimous: King of Aragon, Naples, and Sicily, 1396-1458. New York: Clarendon Press/Oxford University Press.

19. Amelang, James. (2006) 'Exchanges between Italy and Spain: Culture and religion' In: Spain in Italy: Politics, Society, and Religion 1500-1700, Dandelet, Thomas and Marino, John, eds. Leiden, Netherlands: Brill. p. 431-455.

20. See: Rubin, Nancy. (1991) Isabella of Castile: The First Renaissance Queen. New York: St. Martin's Press; O'Callaghan, Joseph F. (2004) Reconquest and Crusade in Medieval Spain. Philadelphia: University of Pennsylvania Press; Kamen, Henry. (2014) The Spanish Inquisition: A Historical Revision, $4^{\text {th }}$ ed. New Haven, CT: Yale University Press; Sabatini, Raphael. (1913) Torquemada and the Spanish Inquisition, 2001 reprint. Cornwall, UK: House of Stratus; Monter, E. William. (2003) Frontiers of Heresy: The Spanish Inquisition from the Basque Lands to Sicily. New York: Cambridge University Press.
21. See: Kann, Robert A. (1980) A History of the Habsburg Empire, 1526-1918, 2nd ed. Berkeley: University of California Press; Wheatcroft, Andrew. (1995) The Habsburgs: Embodying Empire. New York: Viking.

22. Benigno, Francesco. (2006). 'Integration and conflict in Spanish Sicily'. Cochrane, Lydia G., trans. In: Spain in Italy: Politics, Society, and Religion 1500-1700, Dandelet, Thomas and Marino, John, eds. Leiden, Netherlands: Brill. p. 21-44; Barbagallo, Salvatore. (2017) La Guerra di Messina, 1674-1678: "Chi protegge li ribelli d'altri principi, invita i popri a' ribellarsi". Naples: Guida.

23. Klarer, Mario, ed. (2018) Piracy and Captivity in the Mediterranean, 1550-1810. New York: Routledge; Davis, Robert C. and Slaves, Christian. (2003) Muslim Masters: White Slavery in the Mediterranean, the Barbary Coast, and Italy, 1500-1800. New York: Palgrave Macmillan; Tinniswood, Adrian. (2011) Pirates of Barbary: Corsairs, Conquests and Captivity in the Seventeenth-Century Mediterranean. New York: Riverhead Books; Konstam, Angus. (2016) The Barbary Pirates, $15^{\text {th }}-17^{\text {th }}$ Centuries. London: Osprey; Marine Research Society. (1993) The Pirates Own Book: Authentic Narratives of the Most Celebrated Sea Robbers. New York: Dover. pp. 424-460; Mosca, E. Agateno. (2009) 'Pirates, Blacks and Mediterranean Pirates'. In: Encyclopedia of Blacks in European History and Culture, Martone, Eric, ed. Westport, CT: Greenwood Press. p. 414-415.

24. Scimone and Triolo, Letojanni, p. 64-65.

25. Keahey, John. (2018) Sicilian Splendors: Discovering the Secret Places that Speak to the Heart. New York: Thomas Dunne. p. 45; Scimone and Triolo, Letojanni, p. 64-65.

26. Scimone and Triolo, Letojanni, p. 64-65.

27. Ibid. p. 65-69.

28. See: Ribot, Luis. (2011) La Rivolta Antispagnola di Messina: Cause e Antecedenti, 1591-1674. Morabito, Stefano, trans. Catanzaro: Rubbettino; Barbagallo, La Guerra di Messina, 1674-1678.

29. Scimone and Triolo, Letojanni, p 69.

30. Ibid. p. 69-72.

31. See: Faulkner, James. (2015) The War of the Spanish Succession, 1701-1714. South Yorkshire, UK: Pen and Sword Books; Lynn, John A. (1999) The Wars of Louis XIV, 1667-1714. New York: Rutledge.

32. Bergamini, John D. (1974) The Spanish Bourbons: The History of a Tenacious Dynasty. New York: G.P. Putnam's Sons; Hargreaves-Mawdsley, W.N., ed. and trans. (1973) Spain under the Bourbons, 1700-1833: A Collection of Documents. Columbia: University of South Carolina Press.

33. Martone, Eric. (2017) 'House of Savoy'. In: Italian Americans: The History and Culture of a People. Martone, Eric, ed. Santa Barbara, CA: ABC-CLIO. p. 45-48; Manconi, Francesco. (2006) 'The Kingdom of Sardinia: A Province in Balance between Catalonia, Castile, and Italy\&\#x2019;. In: Spain in Italy: Politics, Society, and Religion 1500-1700, Dandelet, Thomas and Marino, John, eds. Leiden, Netherlands: Brill. p. $45-72$.

34. See: Acton, Harold. (1957) The Bourbons of Naples, 1734-1825, 1998 reprint. London: Prion Books.

35. Scimone and Triolo, Letojanni, p. 120.

36. Ibid. p. 72

37. Ibid. p. 120.

38. The contemporary Chiesa di San Giuseppe, built in Letojanni during the first half of the twentieth century, was erected on the former site of the Palazzo Reitano, originally constructed in the mid-seventeenth century. See: Scimone and Triolo, Letojanni, p. 72-73, 83.

39. Scimone and Triolo, Letojanni, p. 82, 86. Godmother Cristina Galeano was the daughter of Maestro Diego Galeano and Angela Celi, the maternal great-greatgrandparents of celebrated Letojanni doctor and politician, Francesco Durante (1844-1934). Francesco Durante's mother, Giovanna Galeano (d. 1855) was the daughter of Diego Galeano, who was the son of Giovanni di Diego Galeano (d. 1825). Meanwhile, Maestro Matteo Ardizzone's grandfather, Maestro Pascale di Mario Ardizzone (b. 1662), had moved to Acireale from Aci Sant'Antonio, where his family had lived since at least the 1550s. The family is found among the parish 
records of both towns, kept in the Archivio delle diocesi di Acireale. Digital copies of these records are available on FamilySearch. See: Registri ecclesiastici di Aci Sant'Antonio (Catania), 1574-1910. Salt Lake City, Utah: Filmati dalla Genealogical Society of Utah, 1993. https://www.familysearch.org/search/catalog/680857?avail ability=Family\%20History\%20Library: accessed 3 April 2021; Registri ecclesiastici di Acireale (Catania), 1559-1910 (Maria Santissima Annunziata). Salt Lake City, Utah: Filmati dalla Genealogical Society of Utah, 1993. https://www.familysearch.org/ search/catalog/681795?availability=Family\%20History\%20Library: accessed 3 April 2021; Registri ecclesiastici di Acireale (Catania), 1618-1910 (San Michele Arcangelo). Salt Lake City, Utah: Filmati dalla Genealogical Society of Utah, 1993. https://www. familysearch.org/search/catalog/681930?availability=Family\%20History\%20Library: accessed 3 April 2021.

40. Scimone and Triolo, Letojanni, p. 119

41. Even though Gallodoro's overall population also increased at this time, rising from 639 residents in 1861 to 768 residents in 1881, its growth was marginal in comparison. Gallodoro's population would peak at around 900 inhabitants in 1911 before heading into a continued population decline. In comparison, Letojanni's continued to rise, reaching 2,861 residents in 2016. See: National Institute of Statistics (Italy): http://www.istat.it/en/: accessed 3 April 2021.

42. Riveli 1607, Film 2381815, Riveli di beni e anime, Gallodoro (Messina), 1584-1816. Salt Lake City, Utah: Filmati dalla Genealogical Society of Utah, 1994-2004. https:// www.familysearch.org/search/catalog/747688?availability=Family\%20History\% 20Library: accessed 3 April 2021

43. Muto, Giovanni. (2006) 'Noble Presence and Stratification in the Territories of Spanish Italy.' Cochrane, Lydia G., trans. In: Spain in Italy: Politics, Society, and Religion 1500-1700, Dandelet, Thomas and Marino, John, eds. Leiden, Netherlands: Brill. p. 265-266, 267-268.

44. In such cases, these articles are put in parentheses in the accompanying charts.

45 Riveli 1616, Film 2381815, Riveli di beni e anime, Gallodoro (Messina), 1584-1816. Salt Lake City, Utah: Filmati dalla Genealogical Society of Utah, 1994-2004. https:// www.familysearch.org/search/catalog/747688?availability=Family\%20History\% 20Library: accessed 3 April 2021

46. Riveli 1623, Film 2267564, Riveli di beni e anime, Gallodoro (Messina), 1584-1816. Salt Lake City, Utah: Filmati dalla Genealogical Society of Utah, 1994-2004. https:// www.familysearch.org/search/catalog/747688?availability=Family\%20History\% 20Library: accessed 3 April 2021

47. Riveli 1652, Films 2381815 and 7557364, Riveli di beni e anime, Gallodoro (Messina) 1584-1816. Salt Lake City, Utah: Filmati dalla Genealogical Society of Utah, 19942004. https://www.familysearch.org/search/catalog/747688?availability=Family\% 20History\%20Library: accessed 3 April 2021.

48. Scimone and Triolo, Letojanni, p. 120

49. Restifo, Giuseppe. (1998) La popolazione italiana nel Seicento. SIDES. p. 187-206.

50. Scimone and Triolo, Letojanni, p. 120

51. Riveli 1681, Films 1958014 and 1958015, Riveli di beni e anime, Gallodoro (Messina), 1584-1816. Salt Lake City, Utah: Filmati dalla Genealogical Society of Utah, 19942004. https://www.familysearch.org/search/catalog/747688?availability=Family\% 20History\%20Library: accessed 3 April 2021.

52. Riveli 1748, Films 2067852 and 2067853, Riveli di beni e anime, Gallodoro (Messina), 1584-1816. Salt Lake City, Utah: Filmati dalla Genealogical Society of Utah, 1994 2004. https://www.familysearch.org/search/catalog/747688?availability=Family\% 20History\%20Library: accessed 3 April 2021.

53. Rivelo of Antonio Siliato (Siligato), Riveli 1748, Riveli di beni e anime, Gallodoro (Messina), 1584-1816. Salt Lake City, Utah: Filmati dalla Genealogical Society of Utah, 1994-2004. https://www.familysearch.org/search/catalog/747688?availabil ity=Family\%20History\%20Library: accessed 3 April 2021.

54. The 1747-1748 riveli for Mongiuffi Melia, for example, has a separate rivelo for residents of Gallodoro. See: Riveli of Mongiuffi Melia (1747-1748), folios 423-431. Similarly, some riveli for residents of Gallodoro detail property or transactions in Mongiufii Melia. For some examples, see: Riveli 1748, Films 2085495 and 2085496, Riveli di beni e anime, Mongiuffi Melia (Messina), 1593-1816. Salt Lake City, Utah: Filmati dalla Genealogical Society of Utah, 1994-1999, 2004. https:/www.familysearch.org/search/catalog/
747747? availability=Family\%20History\%20Library: accessed 3 April 2021; Riveli 1748 Films 2067852 and 2067853, Riveli di beni e anime, Gallodoro (Messina), 1584-1816. Salt Lake City, Utah: Filmati dalla Genealogical Society of Utah, 1994-2004. https:// www.familysearch.org/search/catalog/747688?availability=Family\%20History\% 20Library: accessed 3 April 2021

55. For example, in the nineteenth century, Don Antonino Cacopardo (d. 1872) sindaco (mayor) of Mongiuffi Melia in the 1860s, was born to Domenico di Antonio Cacopardo (d. 1856) of Gallodoro, who had married Donna Carmela di Don Santo d'Agostino (d. 1841) of Mongiuffi Melia. Don Antonino Cacopardo married his sister-in-law, Donna Giuseppa di Don Leonardo Intilisano, of a notable family in Mongiuffi Melia in 1831.

56. A character named Mosca appears in Ben Johnson's classic play, Volpone and the Alchemist (c. 1605-1606)

57. Rivelo of Antonino Musca (Mosca), no. 109, Riveli 1652, Riveli di beni e anime, Gallodoro (Messina), 1584-1816. Salt Lake City, Utah: Filmati dalla Genealogica Society of Utah, 1994-2004. https://www.familysearch.org/search/catalog/ 747688?availability=Family\%20History\%20Library: accessed 3 April 2021.

58. Rivelo of Catherina Musca (Mosca), no. 53, Riveli 1681, Riveli di beni e anime, Gallodoro (Messina), 1584-1816. Salt Lake City, Utah: Filmati dalla Genealogical Society of Utah, 1994-2004. https://www.familysearch.org/search/catalog/ 747688?availability=Family\%20History\%20Library: accessed 3 April 2021.

59. Rivelo of Diego Musca (Mosca), nos. 215 and 615, Riveli 1681, Riveli di beni e anime, Gallodoro (Messina), 1584-1816. Salt Lake City, Utah: Filmati dalla Genealogical Society of Utah, 1994-2004. https://www.familysearch.org/search/catalog/ 747688?availability=Family\%20History\%20Library: accessed 3 April 2021.

60. Rivelo of Francesca, wife of Antonio Nogariti and widow of Maestro Giacomo Musca (Mosca), no. 577, Riveli 1681, Riveli di beni e anime, Gallodoro (Messina), 1584-1816. Salt Lake City, Utah: Filmati dalla Genealogical Society of Utah, 1994 2004. https://www.familysearch.org/search/catalog/747688?availability=Family\% 20History\%20Library: accessed 3 April 2021

61. Rivelo of Marco Musca (Mosca), no. 85, Riveli 1748, Riveli di beni e anime, Gallodoro (Messina), 1584-1816. Salt Lake City, Utah: Filmati dalla Genealogical Society of Utah, 1994-2004. https://www.familysearch.org/search/catalog/747688?availability=Family \%20History\%20Library: accessed 3 April 2021; Marco Mosca's descendants lived into the nineteenth century, although his male descendants died out. See: Rivelo of Concetta Melita e Mosca, widow of Mario, and Teresa Mosca, no. 347, Riveli 1816 Riveli di beni e anime, Gallodoro (Messina), 1584-1816. Salt Lake City, Utah: Filmati dalla Genealogical Society of Utah, 1994-2004. https://www.familysearch.org/search/ catalog/747688?availability=Family\%20History\%20Library: accessed 3 April 2021.

62. Rivelo of Simone Musca (Mosca), no. 217, Riveli 1681, Riveli di beni e anime, Gallodoro (Messina), 1584-1816. Salt Lake City, Utah: Filmati dalla Genealogical Society of Utah, 1994-2004. https://www.familysearch.org/search/catalog/ 747688?availability=Family\%20History\%20Library: accessed 3 April 2021; Rivelo of Pietro Cacopardo, no. 171, Riveli 1681, Riveli di beni e anime, Gallodoro (Messina) 1584-1816. Salt Lake City, Utah: Filmati dalla Genealogical Society of Utah, 1994 2004. https://www.familysearch.org/search/catalog/747688?availability=Family\% 20History\%20Library: accessed 3 April 2021

63. Rivelo of Don Pietro Musca (Mosca), no. 103, Riveli 1748, Riveli di beni e anime, Gallodoro (Messina), 1584-1816. Salt Lake City, Utah: Filmati dalla Genealogica Society of Utah, 1994-2004. https://www.familysearch.org/search/catalog/ 747688?availability=Family\%20History\%20Library: accessed 3 April 2021; Rivelo of Don Simeone Musca (Mosca), no. 119, Riveli 1748, Riveli di beni e anime Gallodoro (Messina), 1584-1816. Salt Lake City, Utah: Filmati dalla Genealogica Society of Utah, 1994-2004. https://www.familysearch.org/search/catalog/ 747688 ?availability=Family\%20History\%20Library; Don Simeone Mosca was the son of Don Pietro's older brother, Francesco Mosca (b. c. 1693), and his wife, Rosaria. See: Rivelo of Francesco Musca (Mosca), no. 340, Riveli 1748, Riveli di beni e anime, Gallodoro (Messina), 1584-1816. Salt Lake City, Utah: Filmati dalla Genealogical Society of Utah, 1994-2004. https://www.familysearch.org/ search/catalog/747688?availability=Family\%20History\%20Library: accessed 3 April 2021.

\section{ABOUT THE AUTHOR}

Eric Martone is Interim Dean of the School of Education and Associate Professor of History/Social Studies Education at Mercy College in New York, USA. He received his PhD in history from Stony Brook University. Specializing in modern European history, he has over 100 diverse academic publications in the fields of history, cultural studies, and teaching. His current research utilizes contextualized family case studies as a lens to enrich our understanding of the past. His prior publications include the Italian Americans: The History and Culture of a People (2017). 